K. O. Dombrovskyi ${ }^{1}$, Cand. Sc. (Biol.), Assoc. Prof., orcid.org/0000-0001-6965-6989,

O. F. Rylskyi ${ }^{1}$, Dr. Sc. (Biol.), Prof., orcid.org/0000-0002-9631-1828,

P. I. Gvozdiak ${ }^{2}$, Dr. Sc. (Biol.), Prof., orcid.org/0000-0003-0861-1028,

O.V. Sherstoboieva ${ }^{3}$, Dr. Sc. (Agric.), Prof., orcid.org/0000-0001-8239-0847,

Yu. Yu. Petrusha ${ }^{1}$, Cand. Sc. (Biol.), orcid.org/0000-0003-3041-2877
1 - Zaporizhzhia National University, Zaporizhzhia, Ukraine, e-mail: rylsky@ukr.net

2 - A.V. Dumanskiy Institute of Colloid and Water Chemistry of National Academy of Sciences of Ukraine, Kyiv, Ukraine, e-mail:gvozdyak@ukr.net

3 - Institute of Agroecology and Environmental Management of the National Academy of Agrarian Sciences of Ukraine, Kyiv, Ukraine, e-mail: ovsher@ukr.net

\title{
DISTRIBUTION OF INORGANIC NITROGEN COMPOUNDS IN PURIFICATION OF STORM WASTEWATER OF THE ENGINE-BUILDING MANUFACTORY
}

Purpose. To define peculiarities of distribution of nitrates, nitrites, ammonium ions in water and their ratio at biological treatment of storm wastewater of the engine-building manufactory from petroleum products.

Methodology. The efficiency of treatment was tested at real treatment facilities of STF No. 24 Motor Sich Plant, where on different sites of a clearing construction there was determined the content of the Nitrogen compounds in experimental and two control sections of a settler in parallel during purification of wastewater of petroleum products. In the experimental section, purification of storm waters was conducted by means of 76 set "rafts" with a carrier of the "VIYA" type, and in control sections - by means of a biosorbent of "Ekolan-M".

Findings. Comparative characteristic of space-time distribution of ammonium ions, nitrites and nitrates at biological purification of storm wastewater from petroleum products using the synthetic carrier for an immobilization of microorganisms and a biosorbent was given on the basis of the processed data on the Nitrogen inorganic compounds content in water of a clearing construction. According to the results of calculation of the coefficient of relative utilization of Nitrogen by microorganisms during the process of purification of storm wastewater from petroleum products, we found out that process of ammonium nitrification during the summer season is more intense than during the autumn season. A biotechnology for purification of storm wastewater of oil products is offered with use of the floating bearing elements with a fibrous carrier of the "VIYA" type.

Originality. Biological treatment of storm wastewater from oil products using a carrier of the "VIYA" type is a relevant and primary on the way to environmental safety of surface water. Applying this biotechnology, it is possible to reduce the content of inorganic Nitrogen compounds if a vertical placement of the artificial "VIYA" carrier is additionally implemented to the entire depth of the sewage treatment plant channel (down to $3 \mathrm{~m}$ ). To do this, we proposed to use the design of "rafts" with additional vertical frames with a carrier of "VIYA" type.

Practical value. When using "rafts" with a carrier of the "VIYA" type for the treatment of oil-contaminated storm wastewater, the economic indicators improved significantly and operating costs decreased at treatment facilities of Motor Sich JSC. The results obtained are the basis for upgrading existing water biotechnologies and developing new ones where for an intensification of processes of purification of storm wastewater of the industrial enterprises of petroleum products the immobilized microbiocenoses are used. Complex use of the fibrous carrier of the "VIYA" type and higher water plants for biological purification of storm wastewater from petroleum products and Nitrogen inorganic compounds will become the subject of our further research studies.

Keywords: storm wastewater, petroleum products, biological purification of water, nitrates, nitrites, ammonium

Introduction. Water quality problems tend to dominate in today's world while taking account of the nature and scope of ecosystem pollution. As it stands, the growing flow of wastewater into surface water bodies is becoming a global environmental threat [1].

The effectiveness of the technology of treating wastewater before dumping it into natural water bodies is one of the main factors determining the level of anthropogenic pressure on the state of the aquatic environment [2]. During the period of Ukrainian independence, the volumes of unpurified wastewater and storm water almost doubled. At the same time, the downward trend in the efficiency of wastewater treatment constructions intensified due to the deterioration of equipment and its low technological level [3].

The deterioration of surface water quality under the influence of a number of factors requires improving existing and creating new effective and low-energy-intensive treatment technologies that allow purifying and discharging water into natural watercourses without forming local zones of increased concentration of normalized impurities in the zone of mixing with water of the watercourse.

(C) Dombrovskyi K. O., Rylskyi O.F., Gvozdiak P. I., Sherstoboieva O. V., Petrusha Yu. Yu., 2020
The main role in solving the problem of protecting Ukraine's water resources from pollution belongs to the process of treatment of storm sewage. Among the existing methods of wastewater treatment, biological methods are the cheapest and most affordable. Often they are the only methods that can be used in practice. Modern biological wastewater treatment methods are developed, in most cases, using artificial biocenoses in aeration tanks and biofilters.

Microorganisms are the main biological agents that carry out biodegradation, since they have a wide variety of enzymatic systems and are characterized by high metabolic liability. They are able to decompose a wide range of chemically stable compounds, including polycyclic petroleum products and their derivatives [4]. Microorganisms have such a metabolic apparatus that allows them to use oil products and oil as a source of energy and carbon [5].

Literature review. Active strains of microorganisms-destructors are used for biological purification of water from toxic substances - pathogens, but as the research has shown it is not enough. They must be kept in treatment facilities; also special conditions must be created to prevent them from being washed out by a continuous stream of purified water. For this purpose, it is necessary to attach (fix) microorganisms in any carriers inside the treatment apparatus [6]. Carriers of the 
"VIYA" type made of thin chemical textured fiber (TU 996990-89) are increasingly used in Ukraine to immobilize micro biota.

Nowadays, immobilized biocenoses with the participation of microbes and fouling organisms are also finding increasing application for wastewater treatment in sewage treatment plants and liquid toxic waste storage ponds. The possibility of effective treatment of storm sewage from oil products using immobilized microorganisms and fouling organisms on the carrier "VIYA" was proved on practice [7].

For the effective treatment of storm sewage from industrial enterprises, it is necessary to create additional biological hydraulic structures. The intensification of storm water treatment is based on the fact that floating elements - "rafts" are used as hydraulic structures, in the lower surface of which the fiber carrier "VIYA" is fixed, which just increases the ability of biological treatment of storm sewage. Information about the use of such biotechnologies for the effective treatment of surface and wastewater in Ukraine, where floating load-bearing elements in the form of "rafts" with a carrier of "VIYA" type were used, is presented in research work [8].

Unsolved aspects of the problem. Due to the increase in anthropogenic influence on water bodies, the problem of the quality of water and the aquatic environment has become especially acute, which makes it necessary to elucidate the mechanisms by which nutrients enter aquatic ecosystems. Biogenic elements in municipal wastewater, especially compounds of phosphorus and nitrogen are getting into water bodies and lead to their eutrophication. To obtain reasonable efficiency in removing biogenic elements from wastewater, it is necessary to create a system of clear and unambiguous standardization of the maximum permissible discharges of these elements into water bodies with wastewater [9]. The cycle of inorganic nitrogen compounds is of great interest. The degree of trophicity of water bodies and the quality of water in them depend on the quantitative and qualitative composition of nitrogen-containing substances. Nitrogen compounds are characterized by high biological activity; they participate in the metabolic processes of aquatic organisms, and significantly impair the organoleptic properties of water. The main sources of inorganic nitrogen compounds in water are organic substances, as well as industrial and agricultural wastewater.

The content of nitrates, nitrites and ammonium ions is an important indicator of the chemical composition of water; it is used in environmental assessment and normalization of the quality of natural waters [2]. In addition to assessing water quality, information on the content of various forms of nitrogen in water bodies is required when addressing the balance of nutrients, the relationship between the vital processes of aquatic organisms and the chemical composition of water, and others. The issue of the content of nitrates, nitrites, ammonium in the water of a treatment plant during the biological treatment of storm sewage from oil products in the available literature to us is unexplored. For this reason, studies of the fraction of nitrogen-containing compounds during the treatment of storm sewage from oil products in a sewage treatment plant is an urgent and primary task on the path to the environmental safety of surface water bodies that receive storm water after its treatment.

Purpose. The aim of the work is to determine the characteristics of the distribution of nitrates, nitrites, ammonium in water and their ratio in the biological treatment of wastewater of a motor plant from oil products.

Methods. The studies were carried out at the storm water treatment plant (STP) No. 54 of the of Motor Sich plant. The technology of biological wastewater treatment from oil products at the plant's sewage treatment plant involves the use of the Ekolan-M biosorbent in four sections of the sewage treatment plant and water purification due to the expanded clay batch biofilm located at the end of each section of the sewage treatment plant. Therefore, in order to clarify the issue of the efficiency of refining wastewater from oil products, we carried out experimental studies, where in the control of water purification we performed according to the traditional technology, and in experiments, we were applying modern biotechnologies, where immobilized microorganisms and periphyton organisms were used on a fibrous carrier of the "VIYA" type.

The essence of the biotechnology using immobilized biota on a carrier of the "VIYA" type proposed by the authors is illustrated by drawings (Figs. 1, 2).

In the experimental section 1 , metal mounting brackets 3 are mounted to the side walls 2 and wooden beams 5 are mounted to vertical guides 4 of the mounted brackets 3 . They are attached to halyards 6 connected to "rafts" 7,8 . The "rafts" 7,8 have a perforated bottom 9 , which is made of plastic, (e.g. polypropylene). To the perforated bottom 9 of the "rafts" 7, 8, a fiber carrier of the "VIYA" type is fixed along their entire lower plane. Storm wastewater 10 entering the experimental section 1 is cleaned from oil by immobilized microorganisms-destructors and other peripheral organisms on a fibrous carrier. Wastewater treatment occurs at the end of the section through the expanded clay batch biofilm 11. After expanded clay batch 11 , purified water 12 is discharged into the river Mokra Moskovka.

For the treatment of wastewater from oil products 76 "rafts" with a carrier of the "VIYA" type were mounted and installed in the experimental section. The rafts $(1.50 \times 0.54 \mathrm{~m}$ in size) were installed in such a way that they overlapped the entire water surface area of the experimental section of the sewage treatment plant, Fig. 3.

The fibrous carrier of the "rafts" is located in the upper layer of the water column of the sedimentation tank of the treatment plant. In the surface layer of water $(15-20 \mathrm{~cm})$, a significant amount of oil products accumulate, which are in-

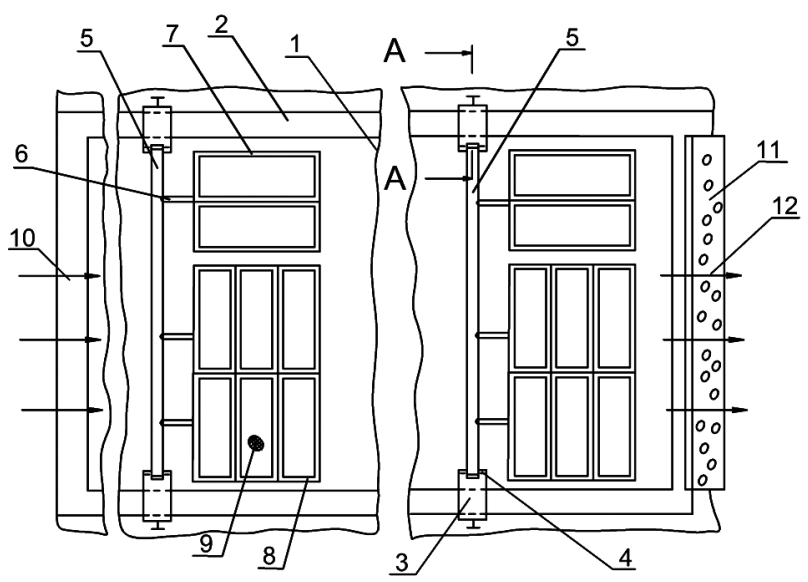

Fig. 1. Overall view of the experimental section of the treatment plant with installed "raft"

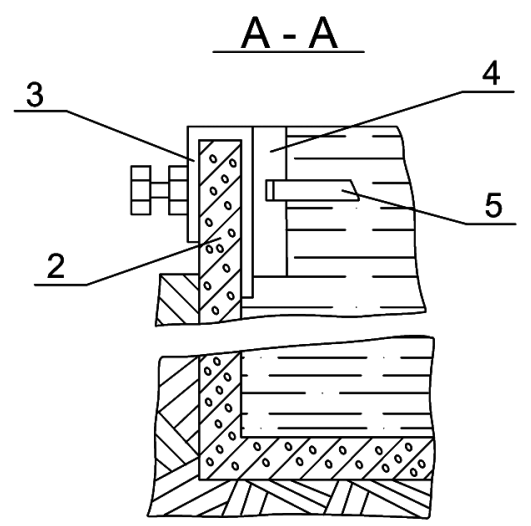

Fig. 2. The intersection of the mounting bracket on $A-A$ 


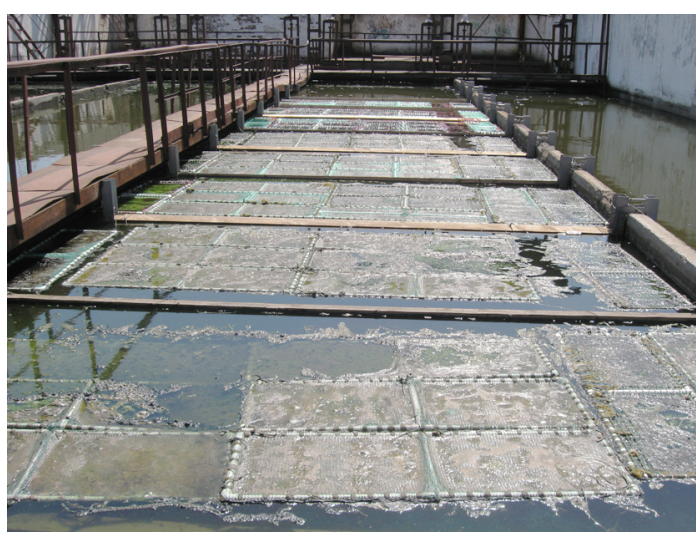

Fig. 3. 76 rafts with fiber carrier "VIYA" installed in the experimental section of the sewage treatment plant of Motor Sich JSC in 2017

tensively oxidized and decomposed by immobilized aerobic microorganisms. A large number of microorganisms-destructors of oil products, formed through the process of immobilization, efficiently use wastewater oil products as a source of energy and carbon. Therefore, the "rafts" with a fibrous support, which are located at the beginning of the experimental section, are not silted with oil, and the mineral substances formed after the decomposition of hydrocarbons gradually settle at the bottom of the treatment plant.

In the control sections, the treatment of storm sewage from oil products was carried out according to traditional technology, with the use of Ekolan-M biosorbent. Due to the fact that the wastewater treatment plant workers use biosorbent only when they visually detect oil pollution in the certain spot of the section, two control sections were used to obtain more reliable results on the effectiveness of wastewater treatment from oil products using this technology.

The composition of the "Ekolan-M" preparation includes carbohydrate-oxidizing actinobacteria Dietzia maris IMB B-7278, Gordonia rubropertincta IMB Ac-5005, Rhodococcus erythropolis IMB B-7012, Rhodococcus erythropolis IMB B-7277 [10] immobilized on a pulverized oil-absorbing sorbent (charcoal).

The option where Ekolan-M biosorbent and "rafts" with a carrier like "VIYA" were not used for the treatment of storm sewage from oil products, was not taken into account due to the number of reasons: firstly, this technology is not provided for by the plant's water treatment scheme, and, secondly, this technology cannot effectively purify storm sewage from oil products and reduce the concentration of oil products in water to the limits of the MPP (as stipulated by the standard of the treatment plant).

The installed "rafts" with a fibrous carrier can be used throughout the year for the treatment of storm sewage during 10-15 years, and then they are replaced. In winter a decrease in water temperature affects the metabolic processes of bacteria; as a result, the intensity of degradation of oil products decreases. But under conditions of ZPF No. 54, the water temperature in the sections does not decrease below $12-13{ }^{\circ} \mathrm{C}$, which does not lead to a complete loss of the destructive ability of the bacterial biofilm on a carrier of the "VIYA" type. In general, to increase the efficiency of wastewater treatment not only from oil products, but also from general pollution in the autumn and winter seasons, it is necessary to use a "VIYA" carrier not only in the surface water layer, but also in the water column using frames with a fibrous carrier. It is worth noting that after installing the rafts, it is not necessary to conduct their constant inspection during their exploitation at the treatment facilities.

The primary immobilization of microorganisms and periphyton organisms on a fiber carrier "VIYA" was carried out in the aerotank of the Central sewage treatment plant of the left bank No. 1 (TsOS-1) of the Zaporizhzhia Vodokanal enterprise for 24 days. Then the fibrous carrier with immobilized organisms was excluded from the TsOS-1 aerotank and transported to ZPF No. 54 of the plant of Motor Sich JSC, where it was placed at the beginning of the experimental section of the sewage treatment plant in front of the "raft" with the fibrous carrier. This was done so that the selected hydrobiocenosis would be faster fixed on a carrier of the "VIYA" type of these floating elements.

At STP No. 54, water samples were taken at the beginning of studied sections, at the end of these sections, and on exit (after expanded clay loading). In the experimental section, water samples were additionally taken in the middle of the section (after 40 "rafts"). In the summer season (June-August) water samples were taken 3 times a month, and in the autumn season in September - 2 times a month, and in November once a month. Totally, 102 water samples were taken for chemical analysis.

The nitrite content in water was determined by diazotization by the Griss reagent with the formation of a red-violet color 1-Naphthylamine diazocompound, which was photometric at a wavelength of $520 \mathrm{~nm}$. The measurement of the mass concentration of nitrate ions was determined colorimetrically by phenol disulfonic acid with the formation of yellow nitrogen-containing phenol. The ammonium content was carried out by the photocolorimetric method in a qualitative reaction with the Nessler reagent at a wavelength of $420 \mathrm{~nm}$.

The concentration of oil products in wastewater was determined by atomic absorption spectrophotometry with the use of electrothermal analyzer - a spectrophotometer "Perkin Elmer" and a flame analyzer "Hitachi $1-80$ " at a wavelength corresponding to the maximum absorption of the investigated element. The concentration of these chemicals in water was determined in the integrated sanitary laboratory of the Motor Sich JSC accredited to technical competence.

Using the concentrations of different forms of mineral nitrogen, we calculated the rate of relative utilization of nitrogen by aqueous microorganisms $\left(K_{N}\right)$ according to the formula [11]

$$
K_{N}=\frac{0.78 \cdot a}{(0.30 \cdot b+0.23 \cdot c)}
$$

where $a, b, c$ are the concentrations of $\mathrm{NH}_{4}^{+}, \mathrm{NO}_{2}^{-}$, and $\mathrm{NO}_{2}^{-}$, respectively, and $0.78,0.30,0.23$ are the mass fraction of Nitrogen in these ions.

The value of $K_{N}>1$ indicates a low level of nitrification of ammonium Nitrogen in the water of the treatment plant. The value $K N<1$ indicates a low activity of the processes of protein ammonification in water. Using the values of this coefficient allows us to evaluate the completeness of the process of Nitrogen transformation in a treatment plant, its completion or violation.

The goal of the implementation of this biotechnology was not a significant decrease in the concentration of nitrogen compounds in storm sewage. This biotechnology was used specifically for the treatment of wastewater from oil products.

Results. Analyzing the data in Table 1, we can note that during June-August, the $\mathrm{NH}_{4}^{+}$content in the experimental section of the sump at the outlet of the treatment plant was 1.12 and 1.14 times lower (average values) than its concentration after storm water treatment in the control sections (No. 1 and No. 2), respectively.

It can be seen from the above data that at the outlet of the treatment plant (after expanded clay loading), the concentration of ammonium nitrogen exceeded the maximum permissible discharge (MPD) $\left(0.552 \mathrm{mg} / \mathrm{dm}^{3}\right)$ in all three studied sections of the clarifier of the treatment plant. During purification of oilcontaminated wastewater by using the "Ekolan" biosorbent in the control sections of the sewage treatment plant, the concen- 
The spatial distribution of nitrogen compounds in water during the treatment of storm sewage from oil products of the Motor Sich JSC plant in the summer season of $2017(M \pm m ; n=6)$

\begin{tabular}{|c|c|c|c|c|c|}
\hline \multirow{3}{*}{$\begin{array}{c}\text { Wastewater collection } \\
\text { point }\end{array}$} & \multicolumn{5}{|c|}{ Forms of Nitrogen } \\
\hline & \multicolumn{3}{|c|}{ Concentration, $\mathrm{mg} / \mathrm{dm}^{3}$} & \multicolumn{2}{|c|}{$\left[\mathrm{NH}_{4}^{+}\right]:\left[\mathrm{NO}_{2}^{-}\right]:\left[\mathrm{NO}_{3}^{-}\right]$} \\
\hline & {$\left[\mathrm{NH}_{4}^{+}\right]$} & {$\left[\mathrm{NO}_{2}^{-}\right]$} & {$\left[\mathrm{NO}_{3}^{-}\right]$} & Quantitative ratio & Quality ratio \\
\hline \multicolumn{6}{|c|}{ The experimental section of the sump, where "VIYA" fiber carrier was used } \\
\hline At the inlet & $1.21 \pm 0.13$ & $0.59 \pm 0.11$ & $4.14 \pm 0.44$ & $1.00: 0.49: 3.42$ & {$\left[\mathrm{NO}_{3}^{-}\right]>\left[\mathrm{NH}_{4}^{+}\right]>\left[\mathrm{NO}_{2}^{-}\right]$} \\
\hline Middle of the section & $1.15 \pm 0.16$ & $0.62 \pm 0.16$ & $4.17 \pm 0.50$ & $1.00: 0.54: 3.63$ & {$\left[\mathrm{NO}_{3}^{-}\right]>\left[\mathrm{NH}_{4}^{+}\right]>\left[\mathrm{NO}_{2}^{-}\right.$} \\
\hline End of the section & $1.18 \pm 0.23$ & $0.55 \pm 0.13$ & $4.58 \pm 0.54$ & $1.00: 0.47: 3.88$ & {$\left[\mathrm{NO}_{3}^{-}\right]>\left[\mathrm{NH}_{4}^{+}\right]>\left[\mathrm{NO}_{2}^{-}\right]$} \\
\hline At the outlet & $1.19 \pm 0.22$ & $0.42 \pm 0.04$ & $4.66 \pm 0.46$ & $1.00: 0.35: 3.92$ & {$\left[\mathrm{NO}_{3}^{-}\right]>\left[\mathrm{NH}_{4}^{+}\right]>\left[\mathrm{NO}_{2}^{-}\right]$} \\
\hline \multicolumn{6}{|c|}{ Control section No. 1, where the "Ekolan" biosorbent was used } \\
\hline At the inlet & $1.38 \pm 0.13$ & $0.68 \pm 0.01$ & $4.55 \pm 0.42$ & $1.00: 0.49: 3.30$ & {$\left[\mathrm{NO}_{3}^{-}\right]>\left[\mathrm{NH}_{4}^{+}\right]>\left[\mathrm{NO}_{2}^{-}\right]$} \\
\hline End of the section & $1.50 \pm 0.23$ & $0.57 \pm 0.04$ & $5.11 \pm 0.67$ & $1.00: 0.38: 3.41$ & {$\left[\mathrm{NO}_{3}^{-}\right]>\left[\mathrm{NH}_{4}^{+}\right]>\left[\mathrm{NO}_{2}^{-}\right]$} \\
\hline At the outlet & $1.33 \pm 0.23$ & $0.59 \pm 0.09$ & $4.87 \pm 0.57$ & $1.00: 0.44: 3.66$ & {$\left[\mathrm{NO}_{3}^{-}\right]>\left[\mathrm{NH}_{4}^{+}\right]>\left[\mathrm{NO}_{2}^{-}\right.$} \\
\hline \multicolumn{6}{|c|}{ Control section No. 2, where the "Ekolan" biosorbent was used } \\
\hline At the inlet & $1.38 \pm 0.22$ & $0.61 \pm 0.12$ & $5.00 \pm 0.38$ & $1.00: 0.44: 3.62$ & {$\left[\mathrm{NO}_{3}^{-}\right]>\left[\mathrm{NH}_{4}^{+}\right]>\left[\mathrm{NO}_{2}^{-}\right]$} \\
\hline End of the section & $1.30 \pm 0.17$ & $0.58 \pm 0.11$ & $4.70 \pm 0.37$ & $1.00: 0.45: 3.62$ & {$\left[\mathrm{NO}_{3}^{-}\right]>\left[\mathrm{NH}_{4}^{+}\right]>\left[\mathrm{NO}_{2}^{-}\right.$} \\
\hline At the outlet & $1.36 \pm 0.24$ & $0.55 \pm 0.06$ & $5.26 \pm 0.42$ & $1.00: 0.40: 3.87$ & {$\left[\mathrm{NO}_{3}^{-}\right]>\left[\mathrm{NH}_{4}^{+}\right]>\left[\mathrm{NO}_{2}^{-}\right]$} \\
\hline
\end{tabular}

tration of ammonium in the treated water exceeded the MPD in 13 samples from 18 (72\% of the samples). The highest ammonium content in water was recorded in June $\left(1.96 \mathrm{mg} / \mathrm{dm}^{3}\right)$ and July $\left(2.19 \mathrm{mg} / \mathrm{dm}^{3}\right)$. On the whole, the excess of ammonia MPD in the purified water of the control sections in the summer period was recorded at a level of 1.1 to 4.0 times. In the experimental section of the sump, where storm water was treated with immobilized microorganisms and periphyton organisms on a "VIYA" fiber carrier, the concentration of ammonia nitrogen in the water at the outlet exceeded the MPD of 5 out of 9 samples $(56 \%$ of the samples). The excess of the content of the MPD indicator in the purified water of the experimental section was recorded at a level of 1.3 to 3.5 times.

The minimum $\mathrm{NH}_{4}^{+}$content was recorded in the treated water at the outlet of the treatment plant; this is an average of 1.3 times lower than concentration of an ammonium, comparing to its content in the inlet water. The excess of the $\mathrm{NH}_{4}^{+}$ content of the MPD indicator in the purified water of the experimental section was recorded at 1.4 times, Table 2 .

In the control sections of the sump, the maximum concentration of ammonium in the autumn season was also found at the inlet to the treatment plant. The minimum $\mathrm{NH}_{4}^{+}$content was recorded in the water at the outlet, after its purification, where the ammonium concentration decreased by 1.2 and 1.1 times compared with the maximum values. In the control sections of the sewage treatment plant, the concentration of ammonia of purified water exceeded the MPD in 5 samples out of 6 ( $83 \%$ of the samples). In September-November, in the control sections, an excess of the ammonia nitrogen concentration limit in the outlet water after its purification was found to be from 1.6 to 2.9 times, and by average values $-2.1-2.4$ times.

In the experimental section during the summer season, we recorded the maximum nitrite content $\left(1.20\right.$ and $\left.1.17 \mathrm{mg} / \mathrm{dm}^{3}\right)$ in June and their minimum content in water $(0.35$ and $\left.0.34 \mathrm{mg} / \mathrm{dm}^{3}\right)$ in August. The excess of the MPD of nitrites $\left(0.42 \mathrm{mg} / \mathrm{dm}^{3}\right)$ in purified water during this period was recorded during the second ten days of July (1.4 times) and during the first ten days of August (1.1 times). The value of the average summer nitrite content in water after its purification (at the outlet) does not exceed the MPD and is within the normal range, Table 1 .
During oil-contaminated wastewater treating in the control sections of the sewage treatment plant, the concentration of nitrites in the treated water (at the outlet) exceeded the MPD in 10 out of 12 samples $(83 \%)$. On the whole, the excess of the MPD of nitrites in purified water of the control sections in the summer season was recorded at a level of 1.1 to 2.4 times (an average of 1.5 times). According to the results of the midsummer nitrite content during storm water treatment, it was found that at the outlet of the treatment plant, the nitrite concentration in water exceeded the MPD in control section No. 1 by 1.4 times, and in control section No. 2 by 1.3 times.

In the autumn season, in the experimental section of the sedimentation tank, the nitrite content in the water at first decreased in the middle and at the end of the section, then, on the contrary, it increased and was within the MPD. In the control sections of the sump during this period, an increase in the MPD of nitrites in purified water was found only in control section No. 1 at a level of 1.2 to 1.3 times. Here, it was also found that the concentration of nitrites in wastewater at the inlet increased by 1.2 times compared to the treated water at the outlet of the treatment plant, on average, Table 2.

The nitrate content in the wastewater during the summer period of the experimental and control sections of the sump at the end of the section and at the outlet after water treatment increased. It was also found that at the outlet of the treatment plant (after expanded clay loading), the concentration of nitrates exceeded the MPD $\left(4.06 \mathrm{mg} / \mathrm{dm}^{3}\right)$ in the experimental section in $50 \%$ of the samples, and in the control sections in $58 \%$ of the samples. In general, the excess of the MPD of nitrates in the purified water of the experimental section and the control sections in the summer season was recorded at an average of 1.4 times.

In the autumn season, the nitrate content in the wastewater, which fell into the experimental and control sections of the sump of the sewage treatment plant, was almost similar. After the process of purification of storm water from oil products in the experimental section and in the control sections, the nitrate content in the purified water increased. During the fall period, the study of excess MPD $\left(4.06 \mathrm{mg} / \mathrm{dm}^{3}\right)$, the content of nitrates in the treated water of the treatment plant was not found.

During oil-contaminated storm sewage of the plant purification in the summer-autumn period, it was found that in the water 
The spatial distribution of nitrogen compounds in water during the treatment of storm sewage from oil products of the Motor Sich JSC plant in the autumn season of $2017(M \pm m ; n=3)$

\begin{tabular}{|c|c|c|c|c|c|}
\hline \multirow{3}{*}{$\begin{array}{c}\text { Wastewater collection } \\
\text { point }\end{array}$} & \multicolumn{5}{|c|}{ Forms of Nitrogen } \\
\hline & \multicolumn{3}{|c|}{ Concentration, $\mathrm{mg} / \mathrm{dm}^{3}$} & \multicolumn{2}{|c|}{$\left[\mathrm{NH}_{4}^{+}\right]:\left[\mathrm{NO}_{2}^{-}\right]:\left[\mathrm{NO}_{3}^{-}\right]$} \\
\hline & {$\left[\mathrm{NH}_{4}^{+}\right]$} & {$\left[\mathrm{NO}_{2}^{-}\right]$} & {$\left[\mathrm{NO}_{3}^{-}\right]$} & Quantitative ratio & Quality ratio \\
\hline \multicolumn{6}{|c|}{ The experimental section of the sump, with "VIYA" fiber carrier } \\
\hline At the inlet & $1.34 \pm 0.26$ & $0.37 \pm 0.06$ & $2.81 \pm 0.87$ & $1.00: 0.28: 2.10$ & {$\left[\mathrm{NO}_{3}^{-}\right]>\left[\mathrm{NH}_{4}^{+}\right]>\left[\mathrm{NO}_{2}^{-}\right]$} \\
\hline Middle of the section & $1.26 \pm 0.29$ & $0.32 \pm 0.02$ & $2.89 \pm 0.87$ & $1.00: 0.25: 2.29$ & {$\left[\mathrm{NO}_{3}^{-}\right]>\left[\mathrm{NH}_{4}^{+}\right]>\left[\mathrm{NO}_{2}^{-}\right]$} \\
\hline End of the section & $1.22 \pm 0.27$ & $0.30 \pm 0.01$ & $2.93 \pm 0.88$ & $1.00: 0.25: 2.40$ & {$\left[\mathrm{NO}_{3}^{-}\right]>\left[\mathrm{NH}_{4}^{+}\right]>\left[\mathrm{NO}_{2}^{-}\right]$} \\
\hline At the outlet & $1.07 \pm 0.32$ & $0.38 \pm 0.02$ & $2.96 \pm 0.89$ & $1.00: 0.36: 2.77$ & {$\left[\mathrm{NO}_{3}^{-}\right]>\left[\mathrm{NH}_{4}^{+}\right]>\left[\mathrm{NO}_{2}^{-}\right]$} \\
\hline \multicolumn{6}{|c|}{ Control section No. 1, where the "Ekolan" biosorbent was used } \\
\hline At the inlet & $1.39 \pm 0.28$ & $0.39 \pm 0.04$ & $2.95 \pm 0.92$ & $1.00: 0.28: 2.12$ & {$\left[\mathrm{NO}_{3}^{-}\right]>\left[\mathrm{NH}_{4}^{+}\right]>\left[\mathrm{NO}_{2}^{-}\right]$} \\
\hline End of the section & $1.25 \pm 0.36$ & $0.37 \pm 0.03$ & $3.04 \pm 0.94$ & $1.00: 0.30: 2.43$ & {$\left[\mathrm{NO}_{3}^{-}\right]>\left[\mathrm{NH}_{4}^{+}\right]>\left[\mathrm{NO}_{2}^{-}\right]$} \\
\hline At the outlet & $1.18 \pm 0.35$ & $0.46 \pm 0.06$ & $3.10 \pm 0.94$ & $1.00: 0.39: 2.63$ & {$\left[\mathrm{NO}_{3}^{-}\right]>\left[\mathrm{NH}_{4}^{+}\right]>\left[\mathrm{NO}_{2}^{-}\right]$} \\
\hline \multicolumn{6}{|c|}{ Control section No. 2, where the "Ekolan" biosorbent was used } \\
\hline At the inlet & $1.48 \pm 0.26$ & $0.38 \pm 0.05$ & $3.25 \pm 0.41$ & $1.00: 0.26: 2.20$ & {$\left[\mathrm{NO}_{3}^{-}\right]>\left[\mathrm{NH}_{4}^{+}\right]>\left[\mathrm{NO}_{2}^{-}\right]$} \\
\hline End of the section & $1.39 \pm 0.38$ & $0.34 \pm 0.04$ & $3.28 \pm 0.46$ & $1.00: 0.25: 2.36$ & {$\left[\mathrm{NO}_{3}^{-}\right]>\left[\mathrm{NH}_{4}^{+}\right]>\left[\mathrm{NO}_{2}^{-}\right]$} \\
\hline At the outlet & $1.31 \pm 0.21$ & $0.37 \pm 0.02$ & $3.31 \pm 0.50$ & $1.00: 0.28: 2.53$ & {$\left[\mathrm{NO}_{3}^{-}\right]>\left[\mathrm{NH}_{4}^{+}\right]>\left[\mathrm{NO}_{2}^{-}\right]$} \\
\hline
\end{tabular}

of all studied sections and in all areas of its treatment (at the beginning, in the middle, at the end of the sump section and at the outlet of the treatment plant), the nitrogen content in the quantitative ratio nitrate in water was high. The content of ammonia nitrogen during water treatment was practically $3-4$ times less in the summer season, and 2-3 times less in the autumn season, respectively, the nitrite content was also minimal, Tables $1,2$.

According to the results of calculating the average values of the coefficient of relative utilization of mineral nitrogen by microorganisms, it was found that in summer these indicators were less than unity in all studied sections of the ZTF (Zaporizhzhia treatment facility) No. 54. Also, a gradual decrease in the values of the coefficient during storm water treatment was recorded from $(0.82-0.86)$ at the inlet to $(0.74-0.78)$ at the outlet of the treatment plant. In general, this coefficient, reflecting the orientation of the biochemical processes of the exchange of organic and mineral nitrogen, indicates a satisfactory level of the process of nitrification of ammonium nitrogen in the summer, Table 3.

The average values of the $K_{N}$ coefficient of wastewater from the studies of sedimentation sections in the autumn period were maximum at the inlet to the sewage treatment plant and slightly decreased at the outlet after wastewater treatment. A $K_{N}$ value of more than one indicates at a low level of the process of nitrification of ammonium nitrogen compared to the summer period. Thus, in the autumn season, there is an imbalance in the processes of mineralization of nitrogen organic substances in the site structure of the plant.

When biological treatment of storm sewage from oil products using the fiber carrier "VIYA" it was found that in the summer season in the experimental section of the sump, the concentration of oil products at the inlet was in the range of $0.571-9.704 \mathrm{mg} / \mathrm{dm}^{3}$, then after 40 rafts and at the end of the section it decreased and after purification at the outlet, the oil content in the water was in the range of $0.134-1.253 \mathrm{mg} / \mathrm{dm}^{3}$.

In general, the concentration of oil products in the experimental section of the sump decreased by almost 19 times, and the efficiency of cleaning storm water from oil products at the outlet of the treatment plant was $85 \%$. In the control sections of the sump during the study period, the concentration of oil products in wastewater, according to average inlet indicators, was $0.385-0.548 \mathrm{mg} / \mathrm{dm}^{3}$; at the end of the sections, the con- centration of oil products increased and ranged within $1.630-2.853 \mathrm{mg} / \mathrm{dm}^{3}$. After expanded clay loading, the average concentration of oil products in the purified water of the control sections at the outlet ranged from $0.190 \mathrm{mg} / \mathrm{dm}^{3}$ to $0.493 \mathrm{mg} / \mathrm{dm}^{3}$. The efficiency of wastewater treatment from oil products in the control sections of the treatment plant using the Ekolan-M biosorbent according to the average indicators at the end of the sections and at the outlet of the treatment plant were 11 and $39 \%$, respectively, Table 4 .

In the autumn season, the concentration of oil products in the experimental section at the inlet was on average $0.447 \mathrm{mg} / \mathrm{dm}^{3}$. During the wastewater treatment process (middle and end of the section), the oil content in the water decreased, and the output was on average $0.121 \mathrm{mg} / \mathrm{dm}^{3}$, it means that, it decreased almost 4 times. In two control sections, the concentra-

Table 3

Average values of the $K_{N}$ coefficient for the treatment of storm sewage from oil products of the plant of Motor Sich JSC in $2017(M \pm m ; n=3-6)$

\begin{tabular}{|l|c|c|c|c|}
\hline \multirow{2}{*}{$\begin{array}{c}\text { Sump of } \\
\text { treatment } \\
\text { facility ZTF } \\
\text { No. 54 }\end{array}$} & \multicolumn{5}{|c|}{ At the inlet } & Middle & End & $\begin{array}{c}\text { At the } \\
\text { outlet }\end{array}$ \\
\cline { 2 - 5 } & \multicolumn{5}{|c|}{ Summer season } \\
\hline $\begin{array}{l}\text { Experimental } \\
\text { section }\end{array}$ & $0.83 \pm 0.02$ & $0.79 \pm 0.03$ & $0.73 \pm 0.09$ & $0.75 \pm 0.09$ \\
\hline $\begin{array}{l}\text { Control } \\
\text { section No. 1 }\end{array}$ & $0.86 \pm 0.04$ & - & $0.85 \pm 0.04$ & $0.78 \pm 0.06$ \\
\hline $\begin{array}{l}\text { Control } \\
\text { section No. 2 }\end{array}$ & $0.82 \pm 0.04$ & - & $0.80 \pm 0.05$ & $0.74 \pm 0.09$ \\
\hline \multicolumn{5}{|c|}{ Autumn season } \\
\hline $\begin{array}{l}\text { Experimental } \\
\text { section }\end{array}$ & $1.50 \pm 0.18$ & $1.34 \pm 0.08$ & $1.28 \pm 0.08$ & $1.01 \pm 0.07$ \\
\hline $\begin{array}{l}\text { Control } \\
\text { section No. 1 }\end{array}$ & $1.46 \pm 0.18$ & - & $1.20 \pm 0.03$ & $1.07 \pm 0.03$ \\
\hline $\begin{array}{l}\text { Control } \\
\text { section No. 2 }\end{array}$ & $1.32 \pm 0.10$ & - & $1.24 \pm 0.12$ & $1.17 \pm 0.04$ \\
\hline
\end{tabular}


tion of oil products in wastewater was $0.472-0.989 \mathrm{mg} / \mathrm{dm}^{3}$, according to average indicators in September-November at the inlet. At the end of these sections, the oil content in the water ranged within $0.164-0.169 \mathrm{mg} / \mathrm{dm}^{3}$, and at the outlet of the treatment plant $-0.128-0.168 \mathrm{mg} / \mathrm{dm}^{3}$. The effectiveness of the treatment of storm sewage from oil products in the experimental and control sections of this treatment plant during the study period, according to average indicators at the outlet of the treatment plant, was at the level of 65 and $61 \%$, respectively.

Thus, it was experimentally established that the efficiency of the plant's treatment of storm sewage from oil products using a fibrous carrier in the summer of 2017 at the end of the section and at the exit, after expanded clay loading, was 6.5 and 2.2 times higher compared to the traditional wastewater treatment technology of this enterprise.

On the whole, the efficiency of treatment of storm sewage from oil products of the Motor Sich JSC plant in the experimental section after 76 rafts with a fiber carrier "VIYA" at the end of the sump was at the average level of $79 \%$. In the control sections (without the use of a fibrous carrier), the average degree of wastewater purification from oil products using the Ekolan-M biosorbent in the summer-autumn period was $51 \%$. That is, the data presented confirm that the efficiency of purification of storm water of a plant from oil products using a fibrous carrier is 1.6 times more efficient than with the classical technology using the Ekolan-M biosorbent.

It should be noted that the Ekolan-M biosorbent at ZTF No. 54 is used in an amount of $50-60 \mathrm{~kg}$ of the preparation for one week. Considering that $1 \mathrm{~kg}$ of the sorbent costs $150-$ $152 \mathrm{UAH}$, then counting for 10 years of operation of the treatment plant, we need to spend 3900 thousand UAH. By using rafts with a fibrous carrier, at ZTF No. 54, 76 $\cdot 4=304$ rafts are required. The cost of 1 raft at the prices of 2017 is 1350 UAH. Therefore, it is necessary to spend only 410.4 thousand UAH. Thus, it can be seen that the use of biosorbent leads to a significant increase in financial costs for the maintenance of the treatment plant system. This is 9.5 times more expensive than the technology for treating wastewater from oil products than the technology using rafts with a carrier of the "VIYA" type.

Conclusion. In storm sewage entering the treatment plant, the content of ammonium, nitrites and nitrates was in the range of $1.21-1.48 \mathrm{mg} / \mathrm{dm}^{3}, \quad 0.37-0.68 \mathrm{mg} / \mathrm{dm}^{3}, 2.81-$ $5.00 \mathrm{mg} / \mathrm{dm}^{3}$, respectively. According to the content of ammonium and nitrite in the water during the process of wastewater treatment from petroleum products, such a pattern is observed: their concentration decreases at the outlet of the treatment plant. Conversely, the concentration of nitrates in the water increases after the treatment of storm water (at the outlet).

Over the entire period of the research in water of all sections of the sump and in all areas of its purification, it was found that the nitrate content in water was high in the quantitative ratio of nitrogen forms. The content of ammonia nitrogen during water treatment was practically 3-4 times less in the summer season, and 2-3 times less in the autumn season, respectively; the nitrite content was also minimal.

Table 4

Efficiency of sewage treatment from oil products of Motor Sich JSC in $2017(M \pm m ; n=3-14)$

\begin{tabular}{|c|c|c|c|}
\hline \multirow{2}{*}{$\begin{array}{c}\text { Terms } \\
\text { of the study }\end{array}$} & \multicolumn{3}{|c|}{ The purification effect, \% } \\
\cline { 2 - 4 } & Middle & End & At the outlet \\
\hline \multicolumn{4}{|c|}{ The experimental section of the sump, with "VIYA" fiber carrier } \\
\hline Summer season & $76.67 \pm 4.80$ & $68.86 \pm 7.20$ & $85.40 \pm 2.46$ \\
\hline Autumn season & $48.43 \pm 15.01$ & $42.80 \pm 15.81$ & $65.13 \pm 9.47$ \\
\hline \multicolumn{4}{|c|}{ Control sections, where the "Ekolan" biosorbent was used } \\
\hline Summer season & - & $10.54 \pm 6.26$ & $38.99 \pm 7.79$ \\
\hline Autumn season & - & $54.90 \pm 15.44$ & $61.37 \pm 15.03$ \\
\hline
\end{tabular}

The recorded average values of the coefficient of relative utilization of mineral nitrogen compounds by microorganisms over the summer period of the research indicate the prevalence of nitrification processes over ammonification processes. In the autumn season, there is an imbalance in the processes of mineralization of nitrogen organic matter in the treatment plant, which is confirmed by $K_{N}$ values that were more than unity.

It has been established that the treatment of storm sewage from the Motor Sich JSC plant with petroleum products using a fiber carrier of the "VIYA" type is 1.6 times more efficient than with the classical technology by using the Ekolan-M biosorbent.

\section{References.}

1. Isaenko, V. M., Madzh, S. M., Panchenko, A. O., \& Bondae, A. M. (2018). Water-supervision measures for enhancing environmental safety of industrial wastewater industrial enterprise. Science-based technologies, 4(40), 437-442. https://doi. org/10.18372/2310-5461.40.13269.

2. Kulikova, D. V., \& Pavlychenko, A. V. (2016). Estimation of ecological state of surface water bodies in coal mining regions as based on the complex of hydrochemical indicators. Naukovyi Visnyk Natsionalnoho Hirnychoho Universytetu, (4), 62-70.

3. The main indicators of water use of Ukraine for 2002. Kiev: State Committee for Water Management of Ukraine.

4. Soroka, Ya.M., Samoylenko, L.S., \& Gvozdiak, P.I. (2001). Strains Pseudomonas fluorescens 3 and Arthobacter sp. 2 - destructors of polycyclic aromatic hydrocarbons. $M i$ crobiological journal, 63(3), 65-70.

5. Gudzenko, T. V., Gorshkova, E. G., Beliaeva, T. A., Rakitska, S. I., Lisiutin, G. V., \& Ivanytsia, V.A. (2015). Biotechnology for the improvement of the marine environment using immobilized microorganism. Scientific Issues Ternopil Volodymyr Hnatiuk National Pedagogical University Series: Biology, 3-4(64), 146-149.

6. Globa, L. I., \& Gvozdak, P. I. (2015). The biological rendering of chemical pathogens harmless is in a water environment. Gigiena i sanitariya, 94(1), 46-50.

7. Rylsky, A. F., Dombrovskii, K. O., Krupey, K.S., \& Petrusha, Yu. Yu. (2016). Biological Treatment of Storm Wastewater at Industrial Enterprise Using the Immobilized Microorganisms and Hydrobionts. Journal of Water Chemistry and Technology, 38(4), 232-237. https://doi.org/10.3103/S1063455X16040081. 8. Dombrovskiy, K., \& Gvozdyak, P. (2018). Biological afterpurification of industrial sewage from hexamethylene diamine using Periphyton communities on the "VIYA" fibrous carrier and on the root system of Eichhomiacrassipes. Hydrobiological Journal, 54(4), 63-71. https://doi.org/10.1615/HydrobJ.v54.i4.60.

9. Shamanskii, S., \& Boichenko, S. (2018). Standardization of maximum permissible discharges of biogenic elements into water bodies with wastewater in Ukraine. Ecological Sciences, 2(21), 119-126.

10. Podgorskiy, V.S., Nogina, T.M., Dumanskaya, T. U., \& Ostapchuk, A. N. (2015). The change of the composition of the paraffin-naphthenic hydrocarbon fraction in the process of biological purification of water from oil. Journal of water chemistry and technology, 37(6), 553-563.

11. Rotay, T. (2016). Enhancement of environmental security of deployment processes water polyutants in ecosystems of eastern sports. Transactions of Kremenchuk Mykhailo Ostrohradskyi National Univercity, 5((100)2), 100-104.

\section{Розподіл неорганічних сполук нітрогену при очищенні стічних вод моторобудівного заводу}

\section{К. О. Домбровський', О. Ф. Рильський', П. І. Гвоздяк²,} О. В. Шерстобоєва 
1 - Запорізький національний університет, м. Запоріжжя, Україна, e-mail: rylsky@ukr.net

2 - Інститут колоїдної хімії та хімії води імені А. В.Думанського НАН України, м. Київ, Україна, е-mail: gvozdyak@ukr.net

3 - Інститут агроекології і природокористування НААН, м. Київ, Україна, e-mail: ovsher@ukr.net

Мета. Визначити особливості розподілу нітратів, нітритів, йонів амонію у воді та їх співвідношення при біологічному очищенні стічних вод моторобудівного заводу від нафтопродуктів.

Методика. Експериментальні дослідження проводили в умовах зливових очисних споруд № 54 заводу АТ «Мотор Січ», де на різних ділянках очисної споруди паралельно визначали вміст сполук нітрогену в експериментальній та двох контрольних секціях відстійника, при очищенні стічної води від нафтопродуктів. В експериментальній секції очищення зливових вод проводили за допомогою 76 встановлених «плотиків» із носієм типу «ВІЯ», а в контрольних секціях - за допомогою використання біосорбенту «Еколан-М».

Результати. На основі опрацьованих даних щодо вмісту неорганічних сполук нітрогену у воді очисної споруди надана порівняльна характеристика просторово-часового розподілу йонів амонію, нітритів та нітратів при біологічному очищенні зливових вод від нафтопродуктів при використанні синтетичного носія, для іммобілізації мікроорганізмів та біосорбенту. За результатами розрахунку коефіцієнту відносної утилізації неорганічних сполук нітрогену мікроорганізмами під час процесу очищення зливових стічних вод від нафтопродуктів встановлено, що процес нітрифікації амонію в літній період проходить інтенсивніше, ніж в осінній період. Запропонована біотехнологія з очищення зливових вод від нафтопродуктів 3 використанням плаваючих несучих елементів із волокнистим носієм типу «ВІЯ».

Наукова новизна. Біологічне очищення зливових стічних вод від нафтопродуктів з використанням носія типу «ВIЯ» $є$ актуальним і першочерговим завданням на шляху до екологічної безпеки поверхневих вод. При застосуванні даної біотехнології можна зменшити вміст неорганічних сполук нітрогену, якщо додатково впровадити вертикальне розміщення штучного носія «ВІЯ» на всю глибину каналу очисної споруди (до 3 м). Для цього нами було запропоновано використовувати конструкцію «плотиків» із додатковими вертикальними рамками з носієм типу «ВІЯ».

Практична значимість. При застосуванні «плотиків» із носієм типу «ВІЯ» при очищенні нафтозабруднених зливових стічних вод значно покращились економічні показники та зменшились експлуатаційні витрати на очисній споруді заводу АТ «Мотор Січ». Отримані результати є основою для вдосконалення існуючих і розробки нових біотехнологій води, де для інтенсифікації процесів очищення зливових вод промислових підприємств від нафтопродуктів використовують іммобілізовані мікробіоценози. Предметом наших подальших досліджень стане комплексне використання волокнистого носія типу «ВІЯ» та вищих водних рослин для біологічного очищення зливових стічних вод від нафтопродуктів і неорганічних сполук нітрогену.

Ключові слова: стічні води, нафтопродукти, біологічне очищення води, нітрати, нітрити, амоній

\section{Распределение неорганических соединений нитрогена при очистке сточных вод моторостроительного завода}

\author{
К. О. Домбровский', А. Ф. Рыльский', П. И. Гвоздяк², \\ Е. В. Шерстобоева ${ }^{3}$, Ю. Ю. Петруша ${ }^{1}$
}

1 - Запорожский национальный университет, г. Запорожье, Украина, e-mail: rylsky@ukr.net

2 - Институт коллоидной химии и химии воды имени А.В. Думанского НАН Украины, г. Киев, Украина, e-mail: gvozdyak@ukr.net

3 - Институт агроэкологии и природопользования НААН, г. Киев, Украина, e-mail: ovsher@ukr.net

Цель. Определить особенности распределения нитратов, нитритов, ионов аммония в воде и их соотношение при биологической очистке сточных вод моторостроительного завода от нефтепродуктов.

Методика. Экспериментальные исследования проводили в условиях ливневых очистных сооружений ЛОС № 54 завода $\mathrm{AO}$ «Мотор Сич», где на разных участках очистного сооружения параллельно определяли содержание соединений нитрогена в экспериментальной и двух контрольных секциях отстойника, при очистке сточной воды от нефтепродуктов. В экспериментальной секции очистку ливневых вод проводили при помощи 76 установленных «плотиков» с насадкой типа «ВИЯ», а в контрольных секциях - с помощью биосорбента «Эколан-М».

Результаты. На основании обработанных данных о содержании неорганических соединений нитрогена в воде очистного сооружения дана сравнительная характеристика пространственно-временного распределения ионов аммония, нитритов и нитратов при биологической очистке ливневых вод от нефтепродуктов при использовании синтетического носителя, для иммобилизации микроорганизмов и биосорбента. По результатам расчета коэффициента относительной утилизации нитрогена микроорганизмами во время процесса очистки ливневых сточных вод от нефтепродуктов, установлено, что процесс нитрификации аммония в летний период проходит интенсивнее, чем в осенний период. Предложена биотехнология для очистки ливневых сточных вод от нефтепродуктов с использованием плавающих несущих элементов с волокнистой насадкой типа «ВИЯ».

Научная новизна. Биологическая очистка ливневых сточных вод от нефтепродуктов при использовании насадки типа «ВИЯ» является актуальным и первоочередным заданием на пути к экологической безопасности поверхностных вод. При применении данной биотехнологии возможно уменьшить содержание неорганических соединений нитрогена, если дополнительно внедрить вертикальное размещение искусственной насадки «ВИЯ» на всю глубину канала очистного сооружения (до 3 м). Для этого нами было предложено использовать конструкцию «плотиков» с дополнительными вертикальными рамками с насадкой типа «ВИЯ».

Практическая значимость. При применении «плотиков» с насадкой типа «ВИЯ» для очистки нефтезагрязненных ливневых сточных вод значительно улучшились экономические показатели и уменьшились эксплуатационный затраты на очистном сооружении завода $\mathrm{AO}$ «Mотор Сич». Полученные результаты являются основой для усовершенствования существующих и разработки новых биотехнологий воды, где для интенсификации процессов очистки ливневых вод промышленных предприятий от нефтепродуктов используют иммобилизованные микробиоценозы. Предметом наших дальнейших исследований станет комплексное использование волокнистого носителя типа «ВИЯ» и высших водных растений для биологической очистки ливневых сточных вод от нефтепродуктов и неорганических соединений нитрогена.

Ключевые слова: сточные воды, нефтепродукты, биологическая очистка воды, нитраты, нитриты, аммоний

Recommended for publication by V.P. Volkov, Doctor of Technical Sciences. The manuscript was submitted 21.04.19. 